GA-A16100

SUMMARY

UC-77

\title{
1170-MW(t) HTGB-PS/C PLANT APPLICATION-STUDY REPORT: ALUMINA-PLANT APPLICATION
}

by

R. RAO, A. T. McMAIN, JR., and J. D. STANLEY

\author{
Prepared under \\ Contract DE-AT03-76SF70046 \\ for the San Francisco Operations Office \\ Department of Energy
}

NOTICE

PORTIONS OF THIS REPORT ARE ILLEGIBLE. It

has been regrofizeed from the best avallable

copy to permit the broadest possible avail-

ability.

\section{DATE PUBLISHED: MAY 1981}




\section{DISCLAIMER}

This report was prepared as an account of work sponsored by an agency of the United States Government. Neither the United States Government nor any agency Thereof, nor any of their employees, makes any warranty, express or implied, or assumes any legal liability or responsibility for the accuracy, completeness, or usefulness of any information, apparatus, product, or process disclosed, or represents that its use would not infringe privately owned rights. Reference herein to any specific commercial product, process, or service by trade name, trademark, manufacturer, or otherwise does not necessarily constitute or imply its endorsement, recommendation, or favoring by the United States Government or any agency thereof. The views and opinions of authors expressed herein do not necessarily state or reflect those of the United States Government or any agency thereof. 


\section{DISCLAIMER}

Portions of this document may be illegible in electronic image products. Images are produced from the best available original document. 


\section{DISCLAIMER}

This report was prepared as an account of work sponsored by an agency of the United States Government. Neither the United States Government nor any agency thereof, nor any of their employees, makes any warranty, express or implied, or assumes any legal liability or responsibility for the accuracy, completeness, or usefulness of any information, apparatus, product, or process disclosed, or represents that its use would not infringe privately owned rights. Reference herein to any specific commercial product, process, or service by trade name, trademark, manufacturer, or otherwise, does not necessarily constitute or imply its endorsement, recommendation, or favoring by the United States Government or any agency thereof. The views and opinions of authors expressed herein do not necessarily state or reflect those of the United States Government or any agency thereof.

Printed in the United States of America Available from

National Technical Information Service U.S. Department of Commerce 5285 Port Royal Road Springfield, Virginia 22161 
GA-A16100 SUMMARY UC-77

GA-A--16100 Summ.

DE82 007219

\section{0-MW(t) HTGR-PS/C PLANT APPLICATION STUDY REPORT: ALUMINA PLANT APPLICATION}

by

R. RAO, A. T. McMAIN, JR., and J. D. STANLEY

\section{Prepared under \\ Contract DE-AT03-76SF70046 for the San Francisco Operations Office \\ Department of Energy}

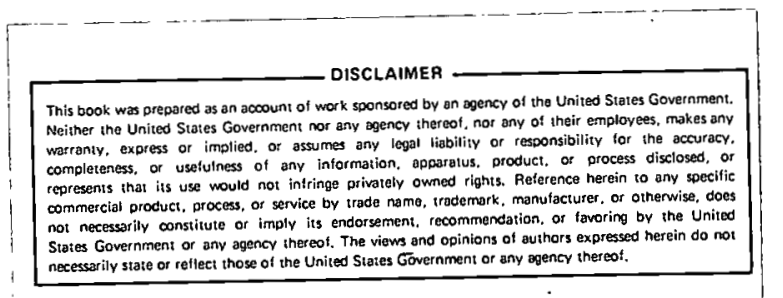

GENERAL ATOMIC PROJECT 6600 DATE PUBLISHED: MAY 1981 
INTRODUCTION

Aluminum refining uses two major energy-intensive processes:

1. Aluminum oxide or alumina is obtained from bauxite via the Bayer chemical process. This process uses a significant amount of steam to react with bauxite and for mechanical drive. It also requires electric power.

2. Alumina is reduced to aluminum by electrolysis. This process requires large amounts of .electric power.

Figure 1 shows a schematic process flow diagram from ore reduction to aluminum production. Most existing commercial aluminum plants use energy from natural gas power plants. Hydroelectric power supplies a very small fraction of the total aluminum industry electric power requirements.

The HTGR-PS/C was developed by General Atomic (GA) specifically for industries which require both steam and electric energy. The GA 1170-MW( $t)$ HTGR-PS/C design is particularly well suited to industrial applications and is expected to have excellent cost benefits over other energy sources. Because the HTGR produces high-temperature, high-pressure steam at conditions identical to those from fossil-fired boilers, a fairly direct substitution can be made for existing large oil or gas-fired industrial boilers. This gives maximum flexibility in establishing cogeneration heat cycles to produce steam at process conditions.

The 1170-MW( $t$ ) high-temperature gas-cooled reactor - process steam/ cogeneration (HTGR-PS/C) is considered to be well suited for application.to both existing and new commercial aluminum plants. Presently, the aluminum industry must switch to sources of energy such as coal or nuclear to 
N

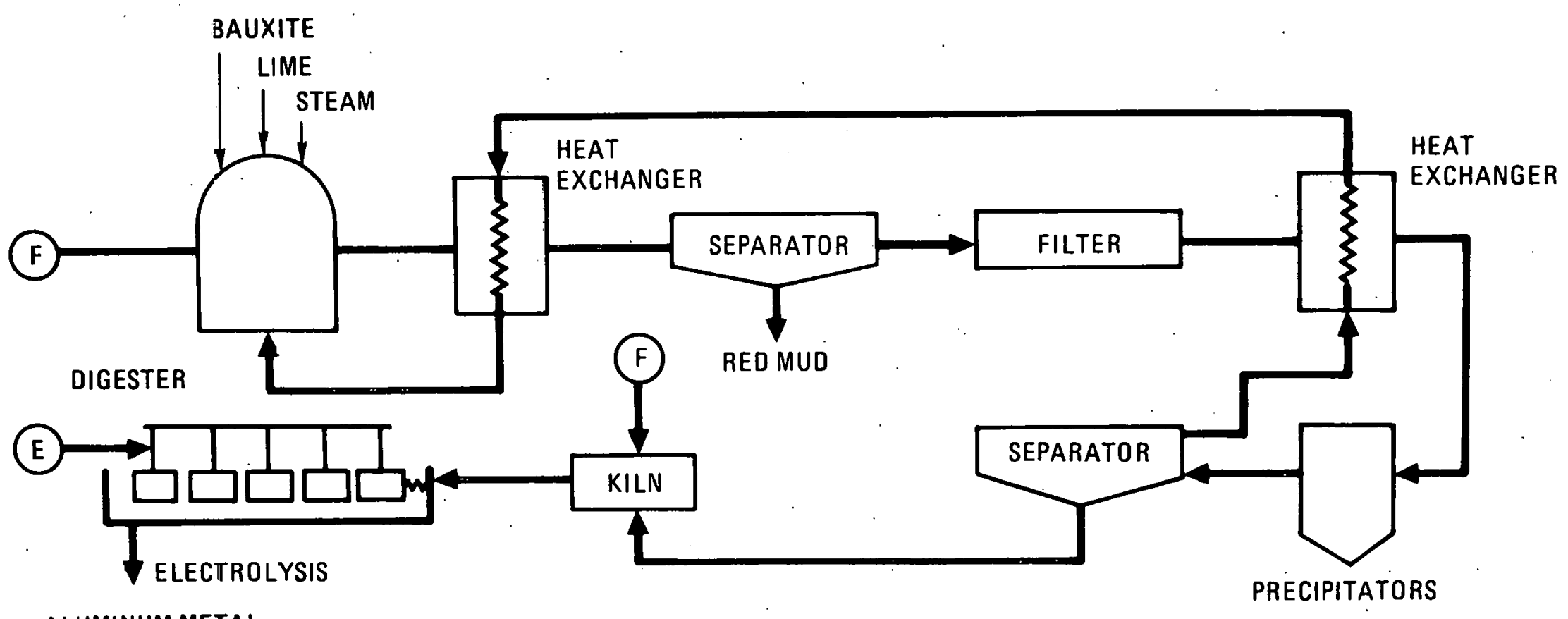

ALUMINUM METAL
E. ELECTRICAL ENERGY INPUT
F = FUEL INPUT 
conserve gas and oil fuels. For the near term, the aluminum industry is most likely to choose coal; however, interest in utilizing a nuclear cogenerating unit is expected, because such a plant is not only cost effective, but it also eliminates many of the cumbersome environmental control issues associated with coal plants.

This report considers the HTGR-PS/C application to producing alumina from bauxite. For the size alumina plant considered, the 1170-MW( $t$ ) HTGRPS/C supplies $100 \%$ of the process steam and electrical power requirements and produces surplus electrical power and/or process steam, which can be used for other process users or electrical power production. Presently, the bauxite ore is reduced to alumina in plants geographically separated from the electrolysis plant. The electrolysis plants are located near economical electric power sources. However, with the integration of an $1170-\mathrm{MW}(t)$ HTGR-PS/C unit in a commercial alumina plant, the excess electric power available [ 233 MW(e)] could be used for alumina electrolysis.

\section{APPLICATION REQUIREMENTS}

Table 1 shows the steam and electrical energy requirements for a typical commercial alumina plant processing 726,680 tonnes ( 800,000 tons) per year of alumina $\left(\mathrm{Al}_{2} \mathrm{O}_{3}\right)$. As indicated, an $1170-\mathrm{MW}(\mathrm{t}) \mathrm{HTGR}-\mathrm{PS} / \mathrm{C}$ could satisfy $100 \%$ of the plant thermal and electric energy requirements. The given breakdown of steam pressure and temperature at various process stages is tentative, pending the availability of a detailed process flow diagram. Possibly, the process and the steam drive system could be modified to better use the higher steam pressure and temperature available from the HTGR-PS/C plant.

\section{PLANT DESIGN}

An 1170-MW( $t$ ) HTGR-PS/C has excess capacity for the process steam and electrical power requirements of the 725,680 tonne $(800,000$ ton) per year alumina plant considered in this study. The excess capacity can produce 
TABLE 1

ENERGY REQUIREMENTS FOR A 726,000 TONNE (800,000 TON) PER YEAR COMMERCIAL ALUMINA PLANT

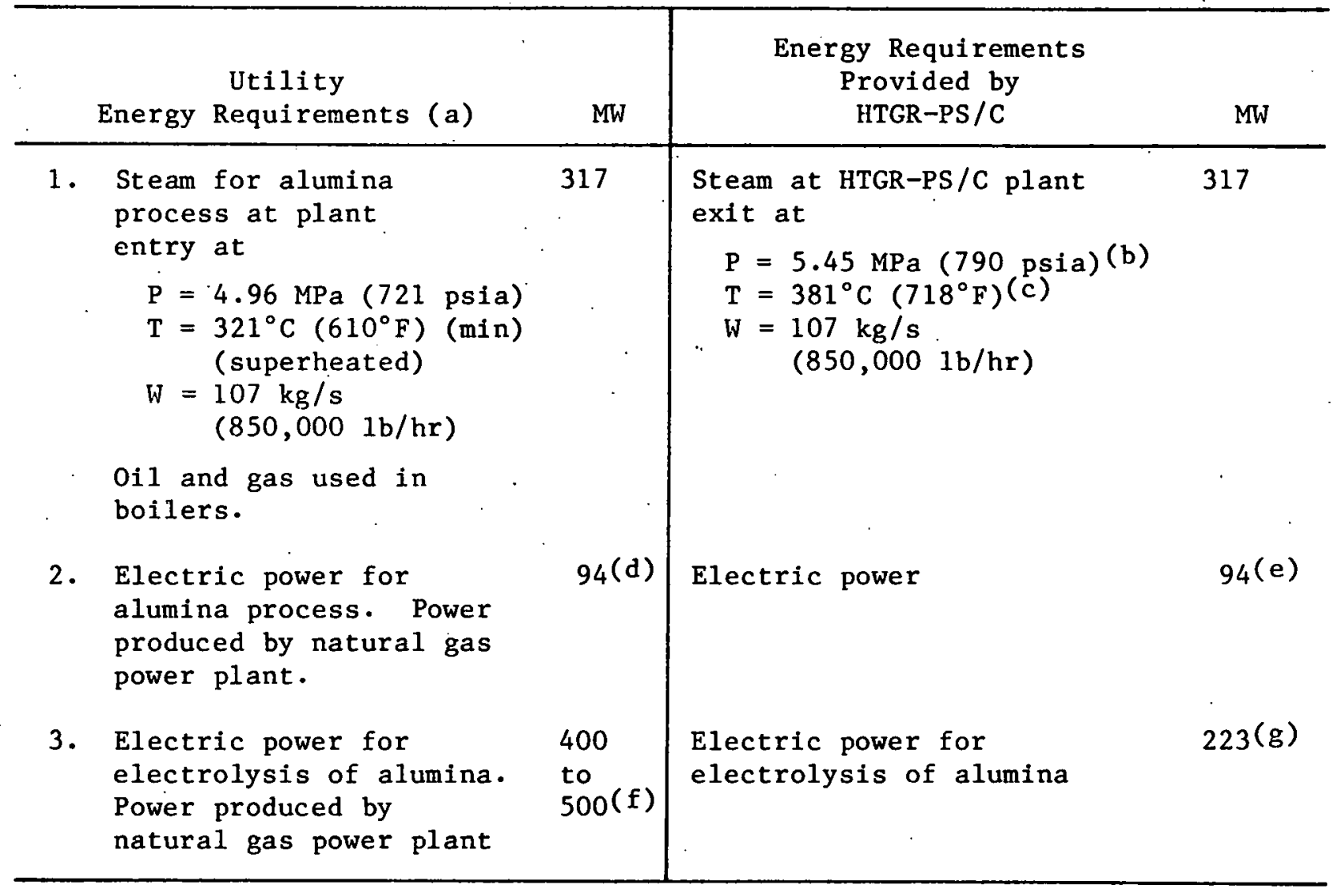

(a) $\mathrm{P}=$ pressure, $\mathrm{T}=$ temperature, $\mathrm{W}=$ flow.

(b) Allows for pressure losses in steam transmission.

(c) Process flow diagram will specify superheat requirements: $381^{\circ} \mathrm{C}$ $\left(718^{\circ} \mathrm{F}\right)$ is offered by steam cycle diagram (see Section 3.1).

(d) Planned to purchase from grid when present natural gas power plant is turned off.

(e) Provided by HTGR-PS/C; the 1170-MW( $t$ ) plant cogenerates more power; see Section 3.1 for more details.

(f) Estimate only.

(g) Electric power available from 1170-MW(t) HTGR-PS/C plant; see Section 3.1 for details. Remaining power from grid. 
additional process steam for sale to other users, additional electric power for sale to a utility or for use by the alumina electrolysis plant, or any desired combination of excess steam and electric power. The local market for other process steam uses, plant economics, proximity of the electrolysis plant, etc., would determine the cycle selected. Two limiting heat cycles have been studied: (1) maximum process steam (Fig. 2) and (2) maximum cogenerated electric power (Fig. 3 ).

The plant entry should have nominal steam conditions of $\sim 4.96 \mathrm{MPa} / 321^{\circ} \mathrm{C}$ $\left(720 \mathrm{psia} / 610^{\circ} \mathrm{F}\right)$; some variation is acceptable. The cycles studied supply steam at $5.45 \mathrm{MPa} / 381^{\circ} \mathrm{C}\left(790 \mathrm{psia} / 718^{\circ} \mathrm{F}\right)$, providing a margin for transmission losses. The alumina plant can provide additional steam conditioning by throttling and/or desuperheating as required.

\section{ECONOMIC ANALYSIS}

The revenue: requirement method was selected to evaluate alternative projects. This technique is appropriate for evaluating long-lived coal and nuclear cogeneration power plant projects. It determines the revenue needed by the firm as compensation for all fixed and variable expenditures. Hence, the revenue requirements of the firm equal the consumer cost for the process steam cogenerated.

Table 2 compares estimated energy costs for the 1170-MW( $t$ ) HTGR-PS/C plant versus a comparable coal-fired PS/C plant for an alumina plant. It. shows a clear advantage for the HTGR over a coal-fired plant.

This analysis is based on economic assumptions used to evaluate utility cogeneration projects in progress for the Department of Energy (DOE) by GA in coordination with Gas Cooled Reactor Associates (GCRA). Table 3 gives the principal assumptions of the economic analysis, a key one being the $18 \%$ fixed charge rate for capital use/recovery. Such a rate may be higher if industrial ownership ground rules are applied. Therefore, the economics 


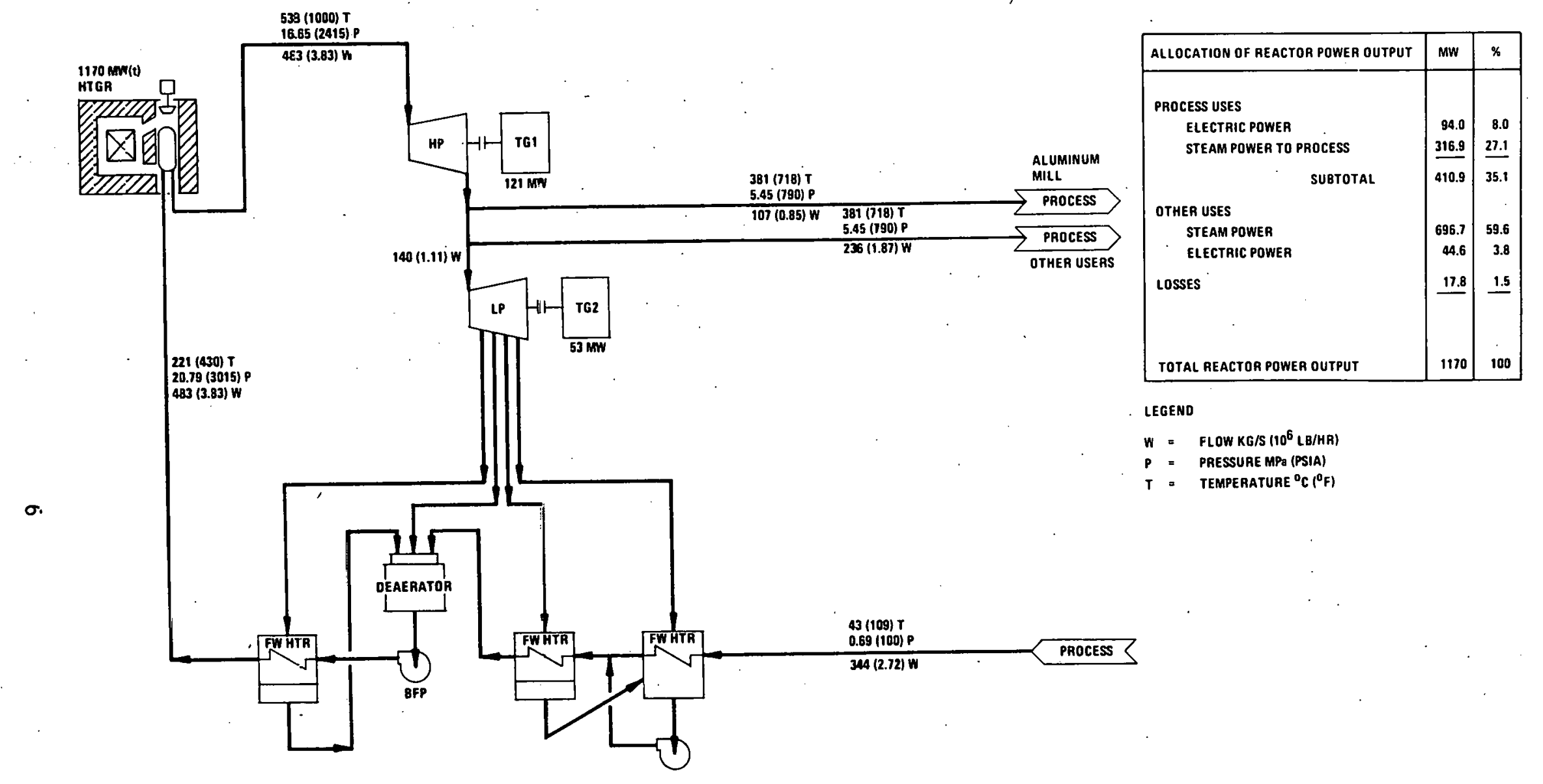

Fig. 2. Cycle diagram for an $1170-M W(t)$ HTGR-PS/C plant for 726,000 tonne $(800,000$ ton) per year aluninum mill application (maximum process steam) 


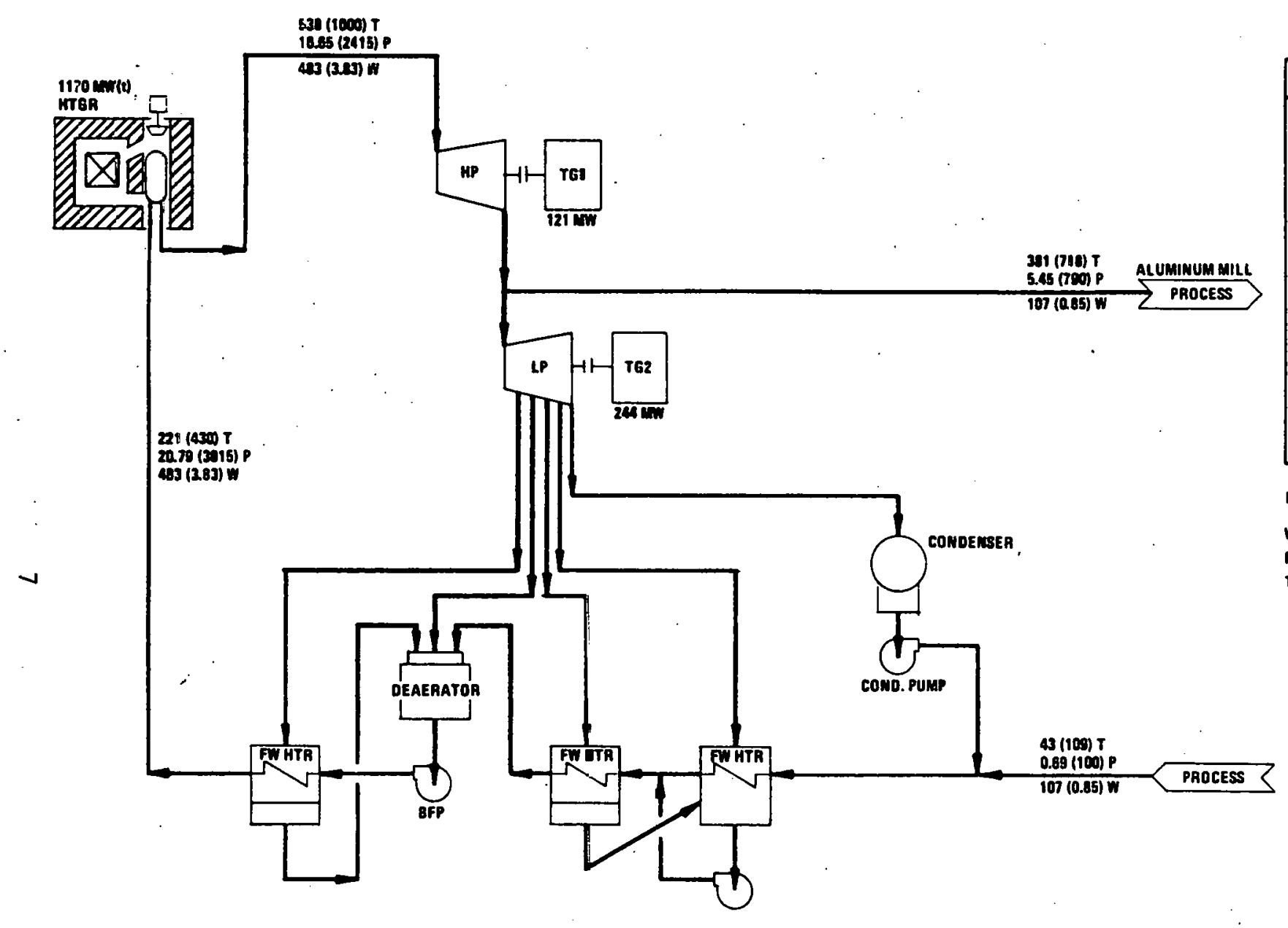

\begin{tabular}{|c|c|c|}
\hline ALLOCATIOM OF REACTOR POWER OUTPUT & mim & $\mathbf{x}$ \\
\hline $\begin{array}{l}\text { PROCESS USES } \\
\text { ELECTRIC POWER } \\
\text { STEAM POWER TO PROCESS }\end{array}$ & $\begin{array}{r}94.0 \\
318.9\end{array}$ & \\
\hline SUETOTAL & $\$ 10.9$ & 35.1 \\
\hline $\begin{array}{l}\text { OTHER USES } \\
\text { ELECTRIC POWER }\end{array}$ & 232.6 & 19.9 \\
\hline $\begin{array}{l}\text { LOSSES } \\
\text { CONDEMSER } \\
\text { OTHER }\end{array}$ & $\begin{array}{r}460.6 \\
45.9 \\
\end{array}$ & $\begin{array}{r}41.1 \\
2.8\end{array}$ \\
\hline TOTAL REACTOR POWER OUTPUT & 1170 & 100 \\
\hline
\end{tabular}

LEGEMO

- FLOW KG/S (100 $18 / \mathrm{HA})$

P. PRESSURE MPQ (PSIA)

$T$ - temperatuae ${ }^{\circ} \mathrm{C}\left({ }^{\circ} \mathrm{F}\right)$

F1g. 3. Cycle diagram for an 1170-MW(t) HTGR-PS/C plant for 726,000 tonne $(800,000$ ton) per year aluminum mill application (maximum cogenerated electrical power) 
TABLE 2

ECONOMIC ANALYSIS OF HTGR-PS/C PLANT VERSUS COAL-FIRED PS/C PLANT FOR ALUMINA PLANT APPLICATION

\begin{tabular}{|c|c|c|c|c|}
\hline - & $\begin{array}{l}\text { HTGR-PS /C } \\
\text { Case } 1\end{array}$ & $\begin{array}{c}\text { Coal-PS } / \mathrm{C} \\
\text { Case } 1\end{array}$ & $\begin{array}{l}\text { HTGR-PS / C } \\
\text { Case } 2 \\
\end{array}$ & $\begin{array}{c}\text { Coal-PS /C } \\
\text { Case } 2 \\
\end{array}$ \\
\hline $\begin{array}{l}\text { Heat input to cycle (MW) } \\
\text { Heat output in process stear (MW) } \\
\text { Net electrical power output (MW) }\end{array}$ & $\begin{array}{r}1170.0 \\
1013.5 \\
138.6\end{array}$ & $\begin{array}{r}1230.2 \\
1013.5 \\
144.7\end{array}$ & $\begin{array}{r}1170.0 \\
317.0 \\
326.6\end{array}$ & $\begin{array}{r}1230.2 \\
317.0 \\
336.0\end{array}$ \\
\hline \multicolumn{5}{|l|}{ Capital Costs $\left(\$ \times 10^{6}\right)$} \\
\hline $\begin{array}{l}\text { Base capital cost }(1 / 80 \$) \\
\text { Escalation through construction } \\
\text { Interest during construction }\end{array}$ & $\begin{array}{l}573 \\
572 \\
359\end{array}$ & $\begin{array}{l}378 \\
427 \\
160\end{array}$ & $\begin{array}{l}658 \\
657 \\
412\end{array}$ & $\begin{array}{l}442 \\
499 \\
188\end{array}$ \\
\hline Total capital cost (1/95 \$) & $\overline{1504}$ & $\overline{965}$ & 1727 & $\overline{1129}$ \\
\hline \multicolumn{5}{|l|}{ Annual Costs $\left(\$ \times 10^{6} /\right.$ year $)(a)$} \\
\hline $\begin{array}{l}\text { Fixed charges } \\
\text { Fuel costs } \\
\text { O\&M costs } \\
\text { Credit for eiectric power }\end{array}$ & $\begin{array}{r}271 \\
81 \\
63 \\
(145)\end{array}$ & $\begin{array}{r}174 \\
299 \\
69 \\
(150)\end{array}$ & $\begin{array}{r}311 \\
81 \\
63 \\
(340)\end{array}$ & $\begin{array}{r}203 \\
299 \\
69 \\
(348)\end{array}$ \\
\hline Total annual costs & 270 & 392 & 115 & 223 \\
\hline $\begin{array}{l}\text { Ṕrocess Steam Cost } \\
{[\mathrm{mills} / \mathrm{kW}(t)-\mathrm{hr}(\$ / M M B t u)]}\end{array}$ & $45.28(12.75)$ & $65.59(18.47)$ & $61.8(17.41)$ & $119.3(33.59)$ \\
\hline $\begin{array}{l}\text { Ratio of energy cost to cost } \\
\text { with HTGR-PS/C }\end{array}$ & -- & 1.4 & -- & 1.9 \\
\hline
\end{tabular}

(a) $1 / 95$ \$ levelized over a 30 -year period. 
TABLE 3

ECONOMIC ANALYSIS ASSUMPTIONS

Commercial operation of all plants: $\quad 1 / 95$

Capacity factor: $\quad 70 \%$

Levelizing period: $\quad 30$ years

Electric power credit: $\quad 22 \mathrm{mills} / \mathrm{kW}-\mathrm{hr}(30 \$)$

Discount rate: $10 \% /$ year

Fixed charge rate: $18 \% /$ year

Interest during construction: $\quad 10 \% /$ year (simple interest)

Coal cost escalation: $8 \% /$ year

Fuel oil escalation: $\quad 9 \% /$ year

Al1 other escalation: $6 \% /$ year

Construction period: $\quad 6$ years for all plants (2 years for No. 6 oilfired plants)

$\mathrm{U}_{3} \mathrm{O}_{8}$ (yellowcake) cost:

$\$ 121 / \mathrm{kg}(\$ 55 / 1 \mathrm{~b})$ in 1990 , rising to $\$ 264 / \mathrm{kg}(\$ 120 /$ 1b) in 2030

Separative work unit (SWU) cost:

$\$ 100 / \mathrm{kg}-$ SWU (80 \$)

Tails assay:

$0.2 \%$

Coal cost:

$4.64 \mathrm{mills} / \mathrm{kW}-\mathrm{hr}(\$ 1.36 /$ MMBtu) (80 \$)

No. 2 oil çost:

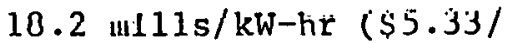
MMBtu) (80 \$)

No. 6 oil cost:

$13.5 \mathrm{mills} / \mathrm{kW}-\mathrm{hr}(\$ 3.95 /$ MMBtu) (80 \$)

HTGR-PS/C fuel cycle cost (includes recycle):

$11.23 \mathrm{mil} 1 \mathrm{~s} / \mathrm{kW}-\mathrm{hr}(\$ 3.29 /$ MMBtu) (1/95 \$ levelized over 30 years) 
should be determined using the economic ground rules appropriate for the specific application. Industrial user input is being developed regarding possible alternative economic ground rules.

Ultimately, the economic analysis method will be determined by the nuclear cogeneration plant ownership:

1. Industrial ownership with connection to the utility grid for backup electric power and sale of excess power (per recent Federal Energy Regulatory Commission rulings regarding a more favorable arrangement for industry).

2. Utility ownership with both steam and cogenerated electric power sold to nearby industry.

3. Consortia ownership and sale of energy to industry and local utilities.

The analysis compares the process steam cost of the HTGR-PS/C versus a coal-fired cogenerating plant. It credits the electric power produced by the HTGR and coal-fired cogenerating plants and indicates a clear advantage for the HTGR over the coal alternative. 